\title{
Book Thieves: Theft and Literary Culture in Nineteenth and
}

\section{Twentieth-century Australia}

In October 1894 retired Presbyterian minister and classical scholar George Graham committed suicide while under suspicion of theft. The elderly Graham had been accused of stealing forty-three texts from Cole's Book Arcade, Melbourne's then world-famous book emporium. The bookstore - one of the largest on the globe suffered regularly from such losses. However, systematic depredations of expensive volumes from the classical department had been noted over a period of eighteen months. Special surveillance was established that identified Graham as the perpetrator. ${ }^{1}$ The missing books bearing Cole's mark were discovered in Graham's private library. Details of the theft, including both Graham's name and street address, were quickly splashed across the newspapers. The story even appeared in other Australian colonies, with one Tasmanian reporter commenting upon the 'unenviable position' his wife and daughter found themselves in. ${ }^{2}$ Unable to face the humiliation of being branded a common thief, Graham cut himself with a razor blade the morning he was due to appear at the City Court, dying of his injuries a few days later. ${ }^{3}$

In actuality, the book thief, or 'biblioklept', was seldom seen as a common criminal. However, such offenders were regarded as a growing nuisance by the turn of the century. Discussions of the stealing encouraged by 'bibliomania' appeared both in Australia and overseas throughout the late nineteenth and early twentieth century. Ironically, this period was a heyday for a literary culture centred upon crime itself: broadsheets and tabloids contained extensive crime coverage; the mystery novel became increasingly popular; and the social explorer genre emerged as non-fiction authors ventured into the realms of the 'criminal classes'. ${ }^{4}$ Given that a sub-stratum of 
vicious and uncultured individuals were held responsible for the overwhelming majority of crime, the book thief presented something of a curiosity to contemporary commentators, and a dilemma to the judiciary. As Clive Emsley suggests, the nineteenth-century construction of crime as a phenomenon committed by a particular social group led to a situation where it was the criminal (or those who conformed to contemporary notions of criminality), rather than crime itself, that was seen as a problem in need of punishment. ${ }^{5}$ Rob Sindall points out that this led to much middleclass crime being ignored or treated leniently. ${ }^{6}$ Book thieves were certainly not ignored, but their treatment by authorities and the media demonstrate that despite their thefts, they were seldom thought of as thieves.

This article deconstructs popular conceptions of the book thief, and contrasts these to the various guises in which book thieves appeared in actual courtrooms. In doing so, I illuminate the complex relationship between theft, literary and consumer culture at the turn-of-the-century period, and consider the effect of cultural discourses on socio-legal outcomes. While my focus is on Melbourne cases, in order to understand the context in which these thefts occurred it is necessary to explore the wider evolution of understandings of thieves and literacy both in Australia and overseas, particularly in England. The book thief discourse was shaped by prevailing expectations of who readers were; that is middle-class males of a scholarly temperament. Such book thieves were in some ways viewed as more aberrant figures than members of the 'criminal classes': rather than being the natural result of heredity or environment, their behaviour was ascribed to mental illness or the modernization of consumer culture. As I will show, such conceptions indicate a failure to recognize the growing democratization of literary culture, and the reading practices of a range of working-class thieves. 
The petty nature of book theft meant most cases were heard before the lower courts. In 1891, for instance, only one case involving book stealing was tried before the Melbourne Supreme Court, and the defendant had stolen other items in addition to the books. ${ }^{7}$ Even in the lower courts, book stealing was not a pervasive issue. Of over 13,000 cases recorded in the City Court of Petty Sessions register in 1891, only fifteen involved book theft. ${ }^{8}$ The comparatively small number of offenders would have made the issue difficult to research prior to the digitization of a large body of Australian newspapers by the National Library. ${ }^{9}$ The Trove newspaper database reveals that the term 'book thief' appears 126 times between the 1890s and 1910s; 'book stealing' is mentioned 116 times across the same period. The reliance of digital databases on optical character recognition technology has methodological limitations in terms of establishing accurate numbers of criminal cases $;{ }^{10}$ however, it does provide a strong basis for a qualitative analysis of obscure offences that simply could not feasibly be achieved by a researcher combing through tens of thousands of court records for the scant details offered on a mere handful of cases. Alongside newspaper accounts though, my analysis draws on a variety of archival and manuscript material, especially memoirs by police and other individuals. I focus particularly on thefts from the repeatedly-victimized Cole's Book Arcade, which was involved in six out of the 15 cases brought to the City Court in 1891.

\section{Book Thieves}

Interest in the subject of book theft became evident in England in the early nineteenth century, when the Reverend Thomas Frognall Dibdin published his massive 618-page tome The Bibliomania; or Book-Madness. ${ }^{11}$ Dibdin described book thieves, readers who suffered the irresistible desire to add to their book collections by theft, as a 
special subset of bibliomaniacs, whose passion for literature extended to the obsessive status of a mania. Originally published in 1811, Didbin's text was reprinted several times in England and America during the second half of the century, when it seems the book thief was becoming a more familiar figure in the Anglo-American zeitgeist. Subsequent accounts of book theft tended to follow Dibdin's lead by focusing their discussions on medieval book thefts or celebrated cases such as Guglielmo Libri's larceny of thousands of books from French libraries in the $1840 \mathrm{~s} .{ }^{12}$ Recent scholarship on book theft has tended to pursue similar terrain. ${ }^{13}$

However, late nineteenth-century and early twentieth-century commentators did not see the book thief as an antiquated or exceptional figure. If anything, the interest in the antecedents of book thieves was due to their familiarity as offenders, albeit ones seen as more comic than dangerous. Only those who regularly encountered the depredations of book thieves tended to take a more serious view of the issue, with articles on how to prevent such thefts published in the American Library Journal and the English Library World from the 1880 s to 1920 s. ${ }^{14}$ This cross-continental discourse entered the Australian public consciousness primarily through the medium of newspapers. Australian broadsheets created an image of the archetypal book thief by presenting historical narratives and humorous anecdotes about book stealing, as well as by reporting real-life cases brought before the courts.

Both magistrates and the media seem to have regarded such hearings as curious, rather than disturbing affairs. This was because the archetypal book thief diverged radically from the expected characteristics of the ordinary criminal. In a typically sardonic manner, one Australian newspaper observed, 'Courage, resource and the philosophic mind, these qualities every successful burglar must possess, but the virtue in particular which singles him out for notice here, and which has not yet 
received due attention, is that which serves most reliably to distinguish him from the honest citizen. The burglar never steals books. ${ }^{15}$ In contrast to professional thieves, the book thief was believed to steal books not for financial gain but 'because he loves them and...feels himself to be their natural and proper if not their legal owner' ${ }^{16}$

This matter of motivation meant that the book thief was seen as different from other thieves, both by themselves and others. When ex-policeman J. M. Kelly was charged with stealing eight books from the Perth public library in 1906, his only defense was that he had no 'evil intent' in taking them. The library saw the matter differently, having lost 350 books to outright theft (not failure to return borrowed books) in the previous three years. However, the magistrate, while hoping the case would deter future offenders, accepted that Kelly had no 'felonious intent' and discharged him on a bond of ten pounds to be of good behavior for two months. ${ }^{17}$ Such treatment was fairly typical of courtroom responses to 'true' book thieves, that is those who stole for reasons other than financial gain.

Of the fifteen cases of book theft adjudicated by Melbourne's City Court in 1891, the defendants were discharged without punishment in five instances. The first fortunate individual to receive such treatment that year was clergyman Christopher Mood, who had stolen a book from the State Library. ${ }^{18}$ Victoria's State Library was the victim in five of the fifteen cases, including the two that attracted the harshest penalties. Frenchman Julius Thomas and James Miller, a Spanish American with 'a weakness for French literature', both received terms of three months imprisonment. ${ }^{19}$ Comments made by Magistrate Joseph Panton suggest ethnic prejudice operated in both cases, Panton condemning the abuse of public institutions by the 'alien'. However, the sentence severity probably also reflected growing unease about book stealing, particularly from public libraries. The issue attracted even more attention in 
September, when Charles Johnston was convicted in the suburban courts of the theft of fifty books from the North Melbourne Library and 200 from the Prahran Library. ${ }^{20}$ Articles appeared arguing that while book theft might not be a serious crime, it was a serious annoyance, particularly when it came to books supplied by public funds. It was also pointed out that the small number of prosecutions was not a reliable indication of the full extent of the problem, as many losses by libraries and stores simply went unreported. ${ }^{21}$ As a result, in December the Victorian Legislature made book stealing from libraries and universities a special offence liable to up to 12 months imprisonment. ${ }^{22}$ Yet while exemplary punishments were occasionally meted out, cautions, fines or light sentences remained the standard response to book theft.

The perception that book theft frequently proceeded not from financial motivation, but from some uncontrollable urge inspired by a love of literature, meant it was often regarded as a form of kleptomania. In a newspaper interview in 1904 a Melbourne book-dealer, who might have been thought to regard such excuses for thefts of his stock quite cynically, declared his belief that all book thieves were kleptomaniacs. ${ }^{23}$ Like book theft, kleptomania emerged in public discourse during the early nineteenth century but became more widely discussed towards the end of the century. With both book theft and kleptomania, the perception that the stealing proceeded from an irresistible impulse was based largely on the fact that those involved were usually of a class who could readily afford to buy the items purloined. Although by the end of the century kleptomania was generally accepted as a medical diagnosis, its effect on legal responsibility remained a contested issue. In the twentieth century Australian jurists proved more receptive than those in England to the notion that being subject to an 'irresistible impulse' constituted a manifestation of exculpatory madness, ${ }^{24}$ but in the 1890 s criticism of the reality of kleptomania and the 
difficulty of proving it meant its use as a defense remained controversial. ${ }^{25}$ However, most cases of book theft, and other forms of shoplifting, were tried under summary jurisdiction at the lower courts, where magistrates were able to accord a great deal of leniency in sentencing without having to explain their reasoning.

The book thief's lack of pecuniary motivation was important, not because it suggested they were subject to an irresistible impulse that precluded the mens rea necessary to commit a crime, but because it meant that despite their crimes they were not seen as criminals. In the nineteenth century the image of the criminal was of an individual born and raised within the dangerous underclasses of society. ${ }^{26}$ Contemporary authorities saw their main duty as preventing the rise of these criminal classes. ${ }^{27}$ But they were also forced to acknowledge that in performing their duties they sometimes had to pursue individuals who, while they committed crimes, were not inherently criminal. As Alfred Burvett commented while reflecting on his career as a Victorian policeman during the 1890 s and early 1900 s, 'It must be remembered that it is not always criminals who commit offences or crimes. ${ }^{, 28}$ Book thieves were among those not regarded as real criminals, in part because their crimes lacked the violence or financial motivations that distinguished offences by the criminal classes, but more importantly because their desire for books - symbols of a higher culture - in itself set them apart from such thieves.

'That the ability to purloin a purse was incompatible with the ability to read is an assumption that permeated nineteenth-century popular culture' asserts Bill Bell in his study of reading practices among transported convicts. ${ }^{29}$ The idea that criminality was fundamentally incompatible with literacy is one with a long history. In England during the Middle Ages, an individual could avoid a criminal trial simply by submitting to a reading test, proof of literacy being accepted as a sign of clerical 
status that rendered individuals exempt from secular punishments. ${ }^{30}$ Despite the gradual democratization of literary culture during the long nineteenth century, ${ }^{31}$ underclass and even working-class individuals continued to be perceived as immune to the type of motivations that led the book thief to steal. Dibdin's authoritative treatise noted that bibliomania 'uniformly confined its attacks to the male sex, and, among these, to people in the higher and middling classes of society, while the artificer, labourer, and peasant have escaped wholly uninjured'. ${ }^{32}$ In 1889, an Australian newspaper similarly commented this 'peculiar form of mania is not confined to people who are in what may be called the criminal classes; on the contrary, it is generally to be found among people of high respectability. ${ }^{33}$ The image of the book thief was tied to the image of the reader, who was a classed and gendered subject.

Book thieves were considered to emanate strictly from the middle classes, in particular from the rarefied gentlemanly class. This perception dates to the early history of book stealing, when scholars and clergy, the main literate members of society, committed the vast bulk of thefts. ${ }^{34}$ Scholars, librarians and clergymen, like the unfortunate Graham, continued to be considered the main perpetrators of book theft. Cases matching this stereotype certainly appeared before local courts. Fifteen months prior to George Graham's arrest, another well-publicized theft from Cole's Book Arcade involved an Oxford graduate employed as a private tutor, who had also stolen a number of books from the University of Melbourne library. ${ }^{35}$ Eight months after this a schoolboy 'of respectable connections' was discharged from court with a warning after stealing a volume of Euclid from Cole's store. Newspapers wrote indulgently of the boy's 'exceptionally intelligent' appearance and laudable desire to compare the book against the translation he was learning from at home. ${ }^{36}$ 
However, it is evident that such stereotypical book thieves were not the only ones who stole books. Even in the medieval period, peasants looting monasteries often carried out book thefts. ${ }^{37}$ Likewise, across the same period as the cases cited above, Cole's also experienced thefts by a bricklayer and sailor. ${ }^{38}$ These individuals failed to arouse the interest or sympathy shown towards the 'respectable' book thief. Although the titles of stolen books were seldom noted in reports, the choice of reading matter perhaps confirmed distinctions as to class and motivation. Youth Richard Walters was sentenced to seven days' imprisonment after stealing two books from Cole's in order to glean instruction in the sport of boxing. ${ }^{39}$ While his theft was not financially motivated, Walters' interest in this working-class pastime was obviously not seen as quite so meritorious as a desire to compare translations of Greek texts.

Rather than an 'irresistible impulse', the common excuse proffered by working-class individuals for book stealing was drunkenness. ${ }^{40}$ It often remains unclear whether the thefts committed under this liquid freeing of inhibitions were inspired by economic motivations, or desire for the books themselves. The masses were not the only ones to indulge in book theft in a drunken freak. Nineteenth-century public servant and Melbourne Gaol Superintendent John Castieau recorded in his diary that he got drunk one night and stole a book from a brothel, where it had been used to prop open a window. ${ }^{41}$ This episode both challenges and crystallizes contemporary notions of who was a reader, and, by extension, a potential book thief. The book was found in a haunt of the underclasses, but the purpose to which it was being put suggested it was not appreciated so much for its literary merit as its physical usefulness. At the same time, its presence there at all is suggestive; especially considering the house belonged not just to criminals, but female criminals. 
Men were considered to form the vast majority of book thieves. Book theft was even described as a male strain of kleptomania, a condition said to effect predominantly women. ${ }^{42}$ The proposition that male kleptomaniacs focused on books while female shoplifters were attracted by the 'odd bit of fine lace' naturally contrasted female superficiality to men's intellectual attainments. ${ }^{43}$ This too was in keeping with perceptions of readers: although women were increasingly literate, their literary tastes were considered light and superficial. ${ }^{44}$ When women stole from Cole's Book Arcade their targets were often fashionable or decorative items the store had on display. ${ }^{45}$ However, there were women who stole books from the store. ${ }^{46}$ Their motivations are at times difficult to discern; but it is clear that such cases, like those of working-class men, were not usually treated by the media as those of 'typical' book thieves.

The book thief discourse also reveals the ambivalence with which Australia regarded itself as a reading nation. Dibdin had associated bibliomania with the English national character, stating that the complex inner-life of the typical Englishman made them particularly prone to the condition. ${ }^{47}$ In contrast, Australians, while clinging to their English roots, were often self-deprecating about their country's literary and intellectual culture. Australian newspaper reports referred to the increasing rate of book theft in Europe and England, but shied away from making such claims in regard to local conditions. ${ }^{48}$ Western Australia in particular regarded itself as a cultural backwater; the West Australian intimated that Perth saw less book stealing than other cities due to the lack of book-collectors among its citizenry. ${ }^{49}$ However, even in cosmopolitan Melbourne, there were those who insisted the locals were not a 'reading public'. ${ }^{50}$ The perception that Australians were not readers was likely encouraged by colonial literature itself, which, particularly by the 1890 s, 
foregrounded 'men of action'. ${ }^{51}$ The outlaw hero was an especially strong tradition in Australian literature, one whose physical prowess and identification with the bush landscape placed them at odds with the developing urban intellectual culture. ${ }^{52} \mathrm{In}$ literature, the thief was considered an exemplar of the nascent national character; book thieves, while objects of sympathy, were not. Thieves in books could not, or did not, read; logically it seemed that people who stole books were not thieves.

\section{Creating thieves}

Book thieves must have books to steal. Despite representations of the colonies as a literary wasteland, Australians were not without reading material. ${ }^{53}$ From 1899 to 1953, Australia was the largest market for British book exports. ${ }^{54}$ Victoria was at the centre of this reading culture. Melbourne had opened the first state-supported public library in Australia in 1853; an institution that, despite the perception of reading as a middle-class activity, was said to be well-patronized by the 'horny-handed sons of labour' ${ }^{55}$ This working-class reading habit was propagated by the ready availability of cheap books, with Melbourne receiving more of Britain's discounted colonial editions than any other port in the British Empire. ${ }^{56}$ In 1900, of the approximately 1,623 booksellers operating in Australia, seventy-two per cent were concentrated in New South Wales and Victoria. ${ }^{57}$ The largest and most famous retailer was unquestionably Cole's Book Arcade, which was established in 1873 by Edward William Cole on Bourke Street, Melbourne. Satellite stores were subsequently opened in other Australian cities, but Melbourne remained the flagship premises, gradually expanding to occupy an entire inner-city block that housed one of the largest stocks of books in the world. ${ }^{58}$ 
Until its closure in 1929 the shop remained one of the marvels of Melbourne, enjoying visits from literary luminaries such as Mark Twain and Rudyard Kipling. It also received a number of less welcome visits from book thieves. The store became a subject of controversy at the turn of the century due to the frequency of these depredations, which seemed to confirm prevailing fears about the effects of modern commercial practices on crime. The furore began in October 1898 during yet another case before the City Court about a theft from the store, this time involving a woman, dressmaker Julia Neil. The presiding magistrate, Joseph Panton, used the hearing as an opportunity to make several disparaging remarks about the store. Panton declared that Cole's Book Arcade created more thieves than any other institution in Melbourne by throwing temptation in the way of people who were 'not really thieves'. ${ }^{59}$ The shop assistant who had observed Neil commit the theft tried several times to interject against the derisive comments made by Panton, but this only caused the magistrate to expand on his theme. In particular, he censured the store's practice of simply letting people 'wander about' the numerous book-filled aisles, rather than keeping the stock behind counters where it would have to be shown to customers by staff.

Panton's belief that Cole's modern approach to retail created biblioklepts out of people who would not ordinarily steal echoed similar views found across the Anglo-American world that blamed the development of the department store for the seemingly growing number of kleptomania cases brought before the courts. As Tammy Whitlock points out, however, the emergence of kleptomania as a subject of debate among legal, medical and retail personnel predates the genesis of the department store by several decades. ${ }^{60}$ Even during the mid nineteenth century, shopkeepers often figured in popular narratives as villains rather than the victims, accused of prosecuting respectable women afflicted by an uncontrollable condition, or 
worse, of stimulating the affliction themselves by their seductive marketing techniques. ${ }^{61}$ Such victim blaming was evident from the mid-century in the colonies as well, with law enforcement officials citing the display of goods outside shopfronts as a prime inducement to shoplifting. ${ }^{62}$ Concerns about kleptomania simply rose to new heights with the appearance of department stores and their innovative sales practices.

Whereas previously customers had told shop assistants what they needed in order to be shown a selection of items, department stores displayed a range of goods intended to entice customers to buy items they may not have originally intended to purchase. ${ }^{63}$ Panton and others objected to this practice of allowing customers to wander about such displays not only because it increased the opportunities for shoplifting, but because it contributed to a new consumer culture in which shopping became a recreational activity. ${ }^{64}$ As well as encouraging frivolous buying, it was believed this led weak-willed women to appease their yearning for the thrill of acquisition through illicit means. ${ }^{65}$ The situation was worsened, contemporaries thought, by the carnival atmosphere department stores cultivated, which led to a sense of normal rules being suspended within their walls. ${ }^{66}$ It is easy then to see why Cole's Book Arcade attracted Panton's ire. Edward Cole believed a visit to his store should be an experience in itself. Not only was he content to allow customers to wander the numerous aisles unsupervised, or actually read books on the premises, but he introduced a number of entertainments to keep visitors on site. Customers were greeted at the entrance by a display of mechanical men holding up rotating advertising boards. A pianist, and in later years, an entire live band, was hired to play music inside. As the premises expanded, Cole established a number of side-shows, including 
a room of fun-house mirrors and a fernery with cages of live monkeys and talking birds. $^{67}$

To Panton's mind, Cole thus enticed customers to thievish behaviour by casting an irresistible allure around his wares. Ironically, the magistrate insisted this evil was compounded by the failure of the store to treat such individuals as ordinary thieves. During Neil's trial, Panton remarked that the shop did not do enough to discourage theft by vigorously pursuing offenders to court. This attitude failed to recognize the awkward position stores were placed in by the thefts of respectable individuals. As Elaine Abelson has shown in her study of female shoplifters in nineteenth-century America, stores who prosecuted affluent clients risked being blacklisted, irrespective of the merits of the case. ${ }^{68}$ The perception that the middleclass defendants involved were incapable of genuine theft, and must therefore either be innocent or suffering from a form of mental illness, meant such prosecutions were seen by some as persecution. Stores thus risked negative publicity in prosecuting thieves.

Within a few days of the Neil trial, the manager of Cole's, William Pyke, published a response to Panton's attack in the Argus defending the store's record of prosecuting thieves. He pointed out that a private detective operated on the premises at all times. ${ }^{69}$ The employment of such agents was becoming more common in Australian department stores by the turn of the century. ${ }^{70}$ While this measure was employed primarily to ward against shoplifters, it was also used to prevent pickpocketing, which was another common problem at Cole's due to the size of the crowds the store attracted. ${ }^{71}$ The prosecution of pickpockets, however, was not controversial in the same way that shoplifters were: not only was the charge brought by the person who had suffered the loss, rather than by the store, but the defendants 
involved tended to belong more clearly to a criminal element. The recriminations a store opened itself up to by prosecuting shoplifters were actually highlighted by the Neil case. Panton's remarks may have had an opposite effect from that he intended, with an article published in 1904 observing that the notoriety brought to Cole's by the magistrate's comments had since made them even more reluctant to prosecute cases. ${ }^{72}$

On the other hand, Cole's reluctance to prosecute thieves may not have been influenced entirely by commercial motives. In addition to being a maverick businessman, Cole was a well-known humanitarian. He used his bookshop to distribute self-published tracts that exhorted temperance and family values, championed women's rights and universal suffrage and criticized the racism of the 'White Australia' immigration policy. Police detective David O'Donnell, recalling his acquaintanceship with Cole in the early 1900s, deplored Cole's clemency towards thieves but attributed it to kindness rather than calculation:

Thieves were constantly being discovered by the attendants, purloining Mr Cole's books, but in his quiet, good natured way, after giving them a fright and making them decidedly uneasy, he usually allowed them to go without giving them in charge to the police, much to the annoyance of the salesmen who caught them. They all agreed that he was altogether too tender-hearted and soft, and so he was. ${ }^{73}$

Cole himself described philanthropically letting a thief escape in a letter to his wife in 1881, writing 'Caught man stealing a book. Said he was really straining poor fellow it seemed a case of real distress gave him a shilling and let him go. ${ }^{74}$ While this case did not involve a book thief as the term was popularly understood, it does suggest that Cole's commitment to social, rather than legal, justice may have inclined him towards leniency when encountering thieves at his store.

Cole had been out of town during the Neil hearing, but upon his return he was quick to defend his establishment, writing his own Argus letter. While Cole took pleasure in making his store into a place of amusement, he clearly believed in its 
value as an educational institution. This influenced his policy of allowing patrons to freely handle and even read books on site. Years after the arcade's closure, a journalist wrote in a tribute to the store that he had 'learned reading, writing and a little arithmetic at school; attended a number of university lectures; and was educated at Cole's book Arcade. ${ }^{75}$ In his response to Panton's condemnation, Cole likened the Book Arcade not to a department store, but a library. He declared that the public library provided similar facilities for theft, but no one would think to disparage this institution. ${ }^{76}$ The Victorian legislature had indeed responded to the frequent thefts from libraries, not by blaming the libraries themselves, but by making book-stealing from public libraries a special offence. ${ }^{77}$ Cole, believing that the educative mission of his store made it akin to such repositories of knowledge, was unable to appreciate Panton's view of it as a centre of crass commercialism serving to demoralize a vulnerable public.

Rather than resting with the responses published by the firm, the issue of whether the ready availability of books turned honest citizens into thieves was raised again less than a fortnight after the Neil hearing when another woman, Ellen Smith, pled guilty to stealing from the store. Not only did Panton use the opportunity to justify his original remarks, but Smith's defence counsel urged that the store should be considered partly responsible for leaving the books without supervision. ${ }^{78}$ Historians have identified such accusations of contributory negligence as a distinctive defence strategy arising out of the kleptomania discourse; however, it should be pointed out that the use of victim blaming as a mitigating circumstance was not unique to shoplifting cases. It is also evident in relation to other middle-class crimes, such as embezzlement. Prison Superintendent John Castieau observed such a case in 1870 , in which a man charged with embezzling twenty thousand pounds was 
recommended to mercy by the jury, who blamed the 'lax discipline' of the bank for giving him the opportunity to commit the theft. ${ }^{79}$ Perceptions of victim fault also sometimes led to sympathetic verdicts in theft cases involving working-class defendants, such as when the person robbed had been drunk or consorting with prostitutes. $^{80}$

Panton, though, clearly differentiated between two different types of offenders. Following the hearing of evidence, the Smith case was remanded to allow the bench time to consider the appropriate sentence. When the hearing resumed several days later, Cole's interest in the matter was no longer being represented just by the police, but by prominent barrister Dr T. P. McInerney, who attempted to have Panton qualify or retract his comments. Panton proved obstinate, citing a recent case in which two boys from reputable families had stolen books from Cole's as proof the store 'made thieves'. He delivered a diatribe against people who expected the courts to protect their property when they did not take the trouble to do so themselves. He then rather contradictorily stated that customers' awareness that they were under surveillance by the store detective had a 'demoralising effect', again echoing arguments that had been raised against such practices overseas. ${ }^{81}$ Panton concluded by caustically commenting that Cole should be pleased by the free publicity he had received from the affair, and sentenced the defendant Smith to a fine of five pounds, or a week's imprisonment. ${ }^{82}$

Ignored throughout the hearing was the fact that Smith was not a true book thief in the popular sense of the term. Not only was she a woman, but she had stolen the books to sell for profit. A number of those accused of book theft in this period were in fact 'old offenders' with previous convictions for theft, whose crimes were discovered when they tried to sell the books to second-hand dealers. ${ }^{83}$ In defiance of 
class expectations though, it was not just professional thieves or working-class miscreants who made use of such practices. In 1913, 158 books stolen from Cole's Book Arcade were thus traced to an engineer employed by the Commonwealth railways. ${ }^{84}$ Five years later a medical student was convicted after trying to sell medical books taken from the store. ${ }^{85}$ The tendency to separate middle-class book thieves from their working-class counterparts based on the presumed distinction between financial and erudite motivations was thus largely arbitrary. While Panton and others believed stores created thieves, it was in fact they themselves who created a special category of thief: one who despite their theft was not seen as a thief at all.

\section{Reading thieves}

The presumption that a fondness for books was incompatible with criminality failed to acknowledge the democratization of reading culture over the course of the nineteenth century. This evolution had itself been stimulated by the perception that illiteracy was a key cause of crime. ${ }^{86}$ Anxiety about the connection between ignorance and criminality meant education assumed a special priority in the Australian penal colonies. Long before the British government was willing to expend money to educate its own populace, it had set aside funds to educate children born in the penal settlements or transported with their parents, in the hope that education would free them from the 'convict taint' and transform them into productive citizens. ${ }^{87}$

Suggesting at the outset the perhaps erroneous connection between criminality and lack of education, many of the teachers first employed in these schools were convicts or ex-convicts. ${ }^{88}$

The penal colonies were also an early site of experiments in prisoner education. Many of the earliest literacy programs involved prisoners awaiting 
transportation on the English hulks; other convicts were taught to read and write on the months-long journey to the colonies. ${ }^{89}$ Towards the end of the transportation period, Alexander Maconochie, Governor of the Norfolk Island prison, instituted a radical program of novel-reading among the convicts, believing that the works of Maria Edgeworth and Jane Austen would provide models of a happy home life to which prisoners might aspire..$^{90}$ The program was abandoned in 1844 when English authorities - horrified by his progressive regime - recalled Maconochie..$^{91}$ The efforts to provide the colonies with a literate populace nevertheless seem to have enjoyed some success, with studies showing that during the early nineteenth century greater literacy prevailed among the locally-born colonial populace than among immigrant settlers. $^{92}$

As transportation to Australia came to a close in the mid nineteenth century, increased interest in reforming prisoners encouraged the adoption of prison literacy programs in England. The type of books available to prisoners initially remained limited to instructive religious works. ${ }^{93}$ The Quakers were the first to support the idea of reading for pleasure among prisoners. ${ }^{94}$ Histories, biographies and other literature slowly began to be included in prison libraries; however, prejudice against novels meant they continued to be proscribed until the second half of the century, when a limited collection of titles were gradually allowed in some institutions. This change resulted from a shift in understanding of the connection between reading and crime, as prison administrators came to believe that it was not the achievement of literacy that was likely to improve a prisoner's chances of rehabilitation, but the self-reflection and mental stimulation a passion for books encouraged. ${ }^{95}$

By the 1850 s the Australian colonies had to some extent fallen behind developments in England, leading to the introduction of an education bill in Victoria 
in 1854 that would make elementary school free and compulsory. The high correlation between illiteracy and criminality was cited in its support. ${ }^{96}$ The bill seemed set to pass until debate arose over whether such education should be religiousbased or secular. Continued inaction meant that by the 1860s the Melbourne clergy were expressing fears for the colony's future if the working classes were left uninstructed. ${ }^{97}$ Their sentiments were shared by judicial authorities such as Justice Thomas Cope, who in 1862 wrote enthusiastically of the connection between civilisation and education. ${ }^{98}$ During the 1860 s and 1870 s, an epidemic of bushranging activity, that is armed robberies taking place in rural locations, was attributed to the ignorance of the colonial-born populace, with most bushrangers said to be as uneducated as the horses they rode. ${ }^{99}$ Finally, in 1872 Victoria became the first Australian colony to institute free, compulsory and secular education; the other colonies all enacted similar legislation by the end of the century. ${ }^{100}$ By 1918 , with near universal literacy, Justice Bevan proclaimed that the declining crime rate that had become apparent in recent decades was due almost entirely to the spread of education. $^{101}$

Yet both historians and contemporaries have questioned the correlation between increasing literacy and decreasing crime. ${ }^{102}$ The assumption that most thieves did not or could not read has also been challenged by the growing body of scholarship on prisoners' encounters with literary culture. This research suggests that criminals adapted literacy to their own purposes. Transportees, for instance, not only brought books with them to the colonies, but commemorated their affection for those they left behind through engraved love tokens and tattoos. ${ }^{103}$ Tattooing persisted as a subcultural tradition among later prisoners. Although many nineteenth-century colonial prisoners were content simply with symbols or initials, some adopted more 
lengthy mottos or epitaphs. Mary Hogan, convicted of robbery in Victoria in 1880, had the words "My Dear Mother" and "I love my mate" inscribed on her left arm. ${ }^{104}$ Other acts also denoted both an engagement in literacy and its use for subversive purposes. Graffiti was a common problem in nineteenth-century prisons. 'Locked in a prison cell, surely it is earthly hell' was among the messages found scrawled on a lockup wall in 1887 by a Royal Commission on the state of the prison system in Queensland. ${ }^{105}$ The Commission reported that the illicit passing of notes between prisoners was another issue, a problem that likewise confronted Superintendent Castieau at the Melbourne Gaol in the 1870s. ${ }^{106}$

While sparse, various anecdotal evidence suggests that criminals also engaged in more ordinary reading practices. Although bushrangers were often held up as emblems of illiteracy, many showed an awareness of the press coverage they had received; one rural bandit even revealed literary tastes by asking a victim if he had read Arabian Nights before stealing a book from him. ${ }^{107}$ Castieau recorded that an inmate of the Melbourne Gaol had been convicted of periodically stealing soap from the lavatory at the Melbourne Library, where he would read every afternoon after closing down the shoeblack stand he operated in the mornings. ${ }^{108}$ In his memoirs, William Manwaring, a police detective in Victoria from 1857 to 1880 , similarly recalled arresting a young Swiss man for uttering valueless cheques after he happened to recognize him when he came across him reading one day in the public library. ${ }^{109}$ David Jones suggests that libraries in Australia have always attracted the unemployed (or underemployed) by providing both a source of daytime accommodation and means to pass the time. ${ }^{110}$

The success of libraries within prisons themselves further intimates that some criminals were at least willing to take up the reading habit. By the early twentieth 
century, Australian prison administrators were boasting of the libraries prisoners possessed, which apart from religious and educational works, contained '[s]tandard authors, such as Dickens, Scott, modern works of fiction, stories of travel and adventure, as well as biographies, and scientific and technical handbooks. ${ }^{, 11}$ In 1901 , Victoria's Inspector-General of Prisons advocated the installation of electric lighting in Pentridge partly in order to allow prisoners to read at night. Even if it did not have a rehabilitative effect, he believed reading helped keep prisoners occupied and compliant. ${ }^{112}$ Not everyone believed that rising literary standards were beneficial when it came to criminals though; in 1888, Australian author Hume Nisbet declared that 'Victoria swarms with State schools and free education, and yet villainy is not stamped out, but rather intensified, by the power which books have given., ${ }^{113}$ 
In England, evidence that literacy in itself did not offer an antidote to criminality meant that by the second half of the nineteenth century concerns had to some extent shifted from the ability of criminals to read, to the content of their reading. Rehabilitative literacy programs like that instituted at Reading Gaol in the 1840s not only prescribed prisoners a diet of religious literature, but sought to instruct them on how to apply such moral lessons to their own lives. ${ }^{114}$ Prison authorities reported that their efforts were hampered by the preference many prisoners had developed prior to imprisonment for adventure fiction, particularly stories involving highwaymen such as Jack Shepherd or Dick Turpin. ${ }^{115}$ Authorities discovered a steady stream of crime novels being smuggled into the gaols by prisoners or their friends. ${ }^{116}$ Castieau experienced similar difficulties. Writing in his diary on 23 April 1871 , he noted that he was currently reading a book confiscated from one of the prisoners, entitled Blueskin, or the Adventures of Jonathan Wild the Great Thief Taker. This text, Castieau declared:

...is certainly as mischievous a work as could possibly gain access to a place of confinement. It describes fully all sorts of different plans \& attempts at Escape made by "Jack Sheppard" \& others $\&$ is just such a book as would fire the imagination of the "larrikin" class who evidently consider "breaking prison" a most heroic exploit \& who would as a rule put up with extra loss of liberty for the glory of appearing in the papers \& being thought "lads of spirit" by their contemporaries. $^{117}$

Concerns about penny-dreadful fiction inspiring local youths to join the rowdy street subculture of 'larrikinism' persisted into the twentieth century. ${ }^{118}$

As Rosalind Crone observes, the statements of criminals themselves did little to dispel these concerns, with prisoners often blaming pernicious reading habits for their descent into crime. ${ }^{119}$ In making such claims these individuals might simply have been trying to conform to the accepted narratives of the pathways into crime expected by their auditors. ${ }^{120}$ However, in an unpublished diary he kept while 
imprisoned at Pentridge in Victoria for breaking and entering in the 1870s, George Edwards similarly recorded that he had always been 'passionately fond of reading', and had been inspired in his criminal pursuits by his addiction to works such as Dick Turpin, Jack Shepherd, Jonathan Wild, The Mysteries of London and Tom Paine.

'With a mind formed upon such literature at an early age,' Edwards asked, 'can it be wondered that I am what I am? ${ }^{, 121}$

The effect of questionable reading matter was of particular concern among female criminals. The assumptions made about women's reading habits and abilities applied even more forcefully to female prisoners. Janet Fyfe's research on England's nineteenth-century prisons reveals that while prison chaplains were quick to trumpet the success of reading programs in male prisons, they were much more critical of the beneficence of reading among women. Female prisoners - like women more generally - were disparaged for their supposed preference for fictional over educational literature, and were said to show a more limited understanding of the instructive moral guides provided to them. ${ }^{122}$ Lower levels of literacy generally prevailed among female prisoners; in Victoria in 1890, for instance, only 658 of 10,660 men imprisoned (6.17 per cent) were illiterate, compared to 384 of 2,796 female prisoners (13.73 per cent). ${ }^{123}$

Female prisoners nevertheless passed the time with oral story-telling, or by literate inmates reading to others. Janet Dibben, a woman imprisoned for infanticide at the Melbourne Gaol in 1888 who later went on to publish several tracts of poetry, wrote that the women spent their days 'telling yarns and singing songs. ${ }^{124}$ During the 1887 prison inquiry Queensland authorities were horrified to learn that prisoners at the colony's main female gaol read aloud in the shared dormitory every night from a copy of The Lady of the Camellias, Alexandre Dumas's account of a Parisian 
courtesan. Newspapers had also been smuggled inside. ${ }^{125}$ Other anecdotes involving female criminals similarly suggest that newspaper reading was common among them. During a procuration case in 1892, a fifteen-year-old girl from the Melbourne suburb of Fitzroy revealed that while her fourteen-year-old friend took clients to bed she would read a newspaper in another corner of the bedroom. ${ }^{126}$ In a later incident, two Melbourne prostitutes who had robbed a man revealed their knowledge of tabloid culture by threatening to slander him in the scandal-sheet Truth if he reported the

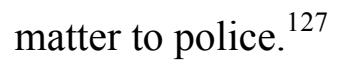

The engagement of criminals with literary culture reveals the fallacy of the distinction between book thieves and other thieves based upon the presumption that thieves did not read. Financially-motivated book theft may not even have been mutually exclusive from literary interests. It was not uncommon for thieves to occasionally reserve stolen items for personal use; individuals were sometimes arrested wearing the clothes they were accused of stealing. ${ }^{128}$ Similarly, in 1876 , a mother and two daughters were prosecuted for stealing a large quantity of merchandise from numerous Melbourne stores, including Cole's Book Arcade. When the police raided their house, among the stolen goods still on the premises was an appropriately chosen copy of Female Life in Prison, which one of the girls was discovered in the act of reading. ${ }^{129}$ Examples of such reading thieves disrupt the way that thieves themselves have traditionally been read, and point to the complex relationship between theft and literary culture in late-nineteenth and early-twentiethcentury Australia.

\section{Conclusion}


While a comparatively trivial offence - even in the view of most contemporaries - book stealing serves to illuminate a number of interesting issues related to crime, reading, gender, class and even national identity. The book thief was a figure who fascinated the Australian public at the turn of the century, but also one who undermined prevailing understandings of criminality. A distinction thus emerged between book thieves and ordinary criminals, who were presumed to be immune to literary propensities. Contemporaries sought to explain the aberrant figure of the book thief in terms of the changes modernity had wrought in the culture of consumption. However, they ignored significant shifts taking place in reading culture itself that challenged the conception of book-lovers - and therefore potential book thieves - as strictly middle-class males with erudite European reading tastes. In reality a variety of people stole books; and thieves engaged in a range of literary practices, from reading translated French novels and adventure literature through to producing their own texts in poetry, diaries and tattoos. Nevertheless, scrutiny of the book thieves brought before the courts shows that conceptions of why people stole - and whether stealing automatically made them 'thieves' - was influenced by who they were perceived to be.

\footnotetext{
${ }^{1}$ Argus, 6 October 1894, p. 7.

${ }^{2}$ Mercury, 13 October 1894, p. 1.

${ }^{3}$ Argus, 17 October 1894, p. 7.

${ }^{4}$ Richard D. Altick, The English Common Reader: A Social History of the Mass Reading Public 18001900 (Chicago, 1983), p. 289.

${ }^{5}$ Clive Emsley, Crime and Society in England, 1750-1900 (London, 1996), p. 121.
} 
${ }^{6}$ Rob Sindall, 'Middle-Class Crime in Nineteenth Century England', Criminal Justice History, 4 (1983), pp. 23-40.

${ }^{7}$ Regina v David Davis, case no. 4, November 1892, VPRS 30/P0, Public Records Office Victoria (hereafter PROV).

${ }^{8}$ VPRS 1665/P0, PROV.

${ }^{9}$ Trove - National Library of Australia newspaper database, https://trove.nla.gov.au/newspaper, accessed 29 July 2015.

${ }^{10}$ Bob Nicholson, 'Counting Culture; or, How to Read Victorian Newspapers from a Distance', Journal of Victorian Culture 17, no. 2 (2012), pp. 238-46.

${ }^{11}$ Thomas Frognall Dibdin, The Bibliomania; or Book-Madness (London, 1811).

${ }^{12}$ William Blades, The Enemies of Books (London, 1880); A. S. W. Rosenbach, Books and Bidders:

The Adventures of a Bibliophile (Boston, 1927); Holbrook Jackson, The Anatomy of Bibliomania

(London, 1930); Lawrence S. Thompson, Notes on Bibliokleptomania (New York, 1944).

${ }^{13}$ Christopher de Hamel, 'Book Thefts in the Middle Ages', in Robin Myers et al (eds), Against the Law: Crime, Sharp Practice and the Control of Print (London, 2004), pp. 1-14; Anthony Hobson, 'Guglielmo Libri', in Robin Myers et al (eds), Against the Law: Crime, Sharp Practice and the Control of Print (London, 2004), pp. 133-150.

${ }^{14}$ Martha A. Bullard, 'Book Thieves', Library Journal 10 (1885), p. 380; M. Hyamson, 'Bibliokleptomania and How to Check It', Library World 8 (1906), pp. 207-208; Edwin White Gaillard, 'The Book Larceny Problem', The Library Journal 45 (1920), pp. 247-54.

${ }^{15}$ West Australian, 14 April 1934, p. 18.

${ }^{16}$ Gaillard, 'The Book Larceny Problem', p. 249.

${ }^{17}$ Truth (Perth), 13 January 1906, p. 5.

${ }^{18}$ Mercury and Weekly Courier, 15 January 1891, p. 3.

${ }^{19}$ Argus, 14 April 1891, p. 6; Argus, 8 May 1891, p. 7.

${ }^{20}$ Argus, 4 September 1891, p. 10; Argus, 11 September 1891, p. 10.

${ }^{21}$ Prahran Telegraph, 14 October 1891, p. 2.

${ }^{22}$ Crimes Act 1891 (Victoria) s 23(1).

${ }^{23}$ Argus, 18 January 1904, p. 5.

${ }^{24}$ Norval Morris, 'The Defences of Insanity in Australia', in Gerhard O. W. Mueller (ed.), Essays in 
Criminal Science (London, 1961), pp. 287-289.

${ }^{25}$ Bendigo Advertiser, 28 February 1891, p. 4; Geelong Advertiser, 28 April 1894, p. 1.

${ }^{26}$ Emsley, Crime and Society in England, p. 72.

${ }^{27}$ Mark Finnane, Police and Government: Histories of Policing in Australia (Melbourne, 1994), p. 97.

${ }^{28}$ Alfred Stephen Burvett, Crimes and Their Detection, 1937, MS 11990, State Library of Victoria (hereafter SLV), p. 28.

${ }^{29}$ Bill Bell, 'Bound for Botany Bay; or, What Did the Nineteenth-Century Convict Read?' in Robin Myers et al (eds), Against the Law: Crime, Sharp Practice and the Control of Print (London, 2004), p. 151.

${ }^{30}$ J. A. Sharpe, Judicial Punishment in England (London, 1990), p. 23.

${ }^{31}$ David Vincent, Literacy and Popular Culture: England 1750-1914, (Cambridge, 1989); Christopher Hilliard, To Exercise Our Talents: The Democratization of Writing in Britain (Cambridge, 2006).

${ }^{32}$ Dibdin, The Bibliomania, pp. 11-12.

${ }^{33}$ Bowral Free Press and Berrima District Intelligencer, 13 March 1889, p. 3.

${ }^{34}$ Hamel, 'Book Thefts in the Middle Ages', pp. 6-7.

${ }^{35}$ Argus, 1 August 1893, p. 6.

${ }^{36}$ The Horsham Times, 20 April 1894, p. 2.

${ }^{37}$ Hamel, 'Book Thefts in the Middle Ages', p. 4.

${ }^{38}$ Argus, 18 July 1893, p. 3; Argus, 22 December 1893, p. 6.

${ }^{39}$ Argus, 11 December 1908, p. 4.

${ }^{40}$ Bairnsdale Advertiser and Tambo and Omeo Chronicle, 14 July 1893, p. 4; Argus, 10 July 1907, p. 9; Argus, 16 August 1909, p. 8; Argus, 8 August 1927, p. 19.

${ }^{41}$ John Buckley Castieau, The Diaries of John Buckley Castieau 1855-1884, 5 February 1855, MS 2218, National Library of Australia.

${ }^{42}$ Daily News, 2 May 1916, p. 4.

${ }^{43}$ Register, 2 January 1903, p. 7.

${ }^{44}$ Martyn Lyons, 'Reading Practices in Australia', in Martyn Lyons et al (eds), A History of the Book in Australia 1891-1945: A National Culture in a Colonised Market (St Lucia, 2001), p. 347.

${ }^{45}$ Argus, 29 December 1887, p. 7; Argus, 18 April 1893, p. 5.

${ }^{46}$ Argus, 24 June 1902, p. 6. 
${ }^{47}$ Dibdin, The Bibliomania, p. 9.

${ }^{48}$ Bowral Free Press and Berrima District Intelligencer, 13 March 1889, p. 3.

${ }^{49}$ West Australian, 14 April 1934, p. 18.

${ }^{50}$ Letter by Edward Oxford, alias John Freeman, to G. H. Haydon, 15 February 1889, MS 16065, SLV.

${ }^{51}$ Lyons, 'Reading Practices in Australia', p. 345.

${ }^{52}$ Tanya Dalziell, 'No Place for a Book? Fiction in Australia to 1890', in Peter Pierce (ed.), The Cambridge History of Australian Literature (Cambridge, 2009), p. 94.

${ }^{53}$ Tim Dolin, 'Fiction and the Australian Reading Public, 1888-1914', in Beth Palmer and Adelene Buckland (eds), Return to the Common Reader: Print Culture and the Novel 1850-1900 (Farnham, 2011), pp. 151-174.

${ }^{54}$ John Arnold, "Newspapers and Daily Reading," in Martyn Lyons et al (eds) A History of the Book in Australia 1891-1945: A National Culture in a Colonised Market (St Lucia, 2001), p. 255.

${ }^{55}$ David J. Jones, 'Public Libraries: "Institutions of the Highest Educational Value”, in Martyn Lyons et al (eds) A History of the Book in Australia 1891-1945: A National Culture in a Colonised Market (St Lucia, 2001), p. 158.

${ }^{56}$ Martyn Lyons, 'Britain’s Largest Export Market', in Martyn Lyons et al (eds), A History of the Book in Australia 1891-1945: A National Culture in a Colonised Market (St Lucia, 2001), p. 19.

${ }^{57}$ John Arnold, Bookshops and Retailing', in Martyn Lyons et al (eds) A History of the Book in Australia 1891-1945: A National Culture in a Colonised Market (St Lucia, 2001), p. 130.

${ }^{58}$ E. Cole Turnley, 'Cole, Edward William (1832-1918)', Australian Dictionary of Biography, http://adb.anu.edu.au/biography/cole-edward-william-3243/text4897, accessed 5 March 2015.

${ }^{59}$ Argus, 26 October 1898, p. 5.

${ }^{60}$ Tammy Whitlock, 'Gender, Medicine, and Consumer Culture in Victorian England: Creating the Kleptomaniac', Albion 31, no. 3 (1999), pp. 413-37.

${ }^{61}$ Ibid., p. 415.

${ }^{62}$ Michael Sturma, Vice in a Vicious Society: Crime and Convicts in Mid-Nineteenth-Century New South Wales (St. Lucia, 1983), pp. 107-108.

${ }^{63}$ Gail Reekie, Temptations: Sex, Selling and the Department Store (St. Leonards, 1993), pp. 14-15.

${ }^{64}$ Ibid., p. 111.

${ }^{65}$ Whitlock, 'Gender, Medicine, and Consumer Culture in Victorian England', p. 435. 
${ }^{66}$ Elaine S. Abelson, When Ladies Go a-Thieving: Middle-Class Shoplifters in the Victorian

Department Store (New York, 1989), p. 143.

${ }^{67}$ Arnold, 'Bookshops and Retailing', pp. 131-132.

${ }^{68}$ Abelson, When Ladies Go a-Thieving, p. 124.

${ }^{69}$ Argus, 27 October 1898, p. 6.

${ }^{70}$ Reekie, Temptations, p. 17.

${ }^{71}$ Argus, 1 February 1894, p. 3; Argus, 22 April 1898, p. 6; Argus, 28 May 1898, p. 11; Argus, 9 July 1903, p. 3 .

${ }^{72}$ Argus, 25 August 1904, p. 5.

${ }^{73}$ D. G. O’Donnell, "Reminiscences of a Victorian Detective," Gisborne Gazette, 16 July 1926, p. 8.

${ }^{74}$ E. W. Cole to Eliza, 25 March 1881, Papers 1875-1903, MS 10111, SLV.

${ }^{75}$ Westralian Worker, 5 November 1943, p. 1.

${ }^{76}$ Argus, 28 October 1898, p. 6.

${ }^{77}$ Crimes Act 1891 (Victoria) s 23(1).

${ }^{78}$ Argus, 5 November 1898, p. 14.

${ }^{79}$ Castieau, Diaries, 23 February 1870.

${ }^{80}$ Castieau, Diaries, 17 February 1874.

${ }^{81}$ Abelson, When Ladies Go a-Thieving, p. 125.

${ }^{82}$ Argus, 9 November 1898, p. 3.

${ }^{83}$ Argus, 11 May 1881, p. 7; Argus, 17 May 1883, p. 4; Argus, 9 March 1894, p. 7; Argus, 19 March 1901, p. 7; Argus, 24 June 1902, p. 6.

${ }^{84}$ Argus, 23 September 1913, p. 13

${ }^{85}$ Argus, 2 August 1918, p. 6.

${ }^{86}$ Altick, The English Common Reader, p. 141.

${ }^{87}$ John F. Cleverley, The First Generation: School and Society in Early Australia (Sydney, 1971), pp. $4-5$.

${ }^{88}$ Ibid., p. 26.

${ }^{89}$ Bell, 'Bound for Botany Bay', p. 154; 162.

${ }^{90}$ John Clay, Maconochie's Experiment (London, 2001), pp. 99-100; Alexander Maconichie, Norfolk Island (London, 1848), pp. 7; 21. 
${ }^{91}$ Hartley, 'Reading in Gaol', pp. 93-94.

${ }^{92}$ Cleverley, The First Generation, p. 134.

${ }^{93}$ Helen Rogers, “'Oh, what beautiful books!” Captivated Reading in an Early Victorian Prison',

Victorian Studies 55.1 (Autumn 2012): 57-84.

${ }^{94}$ Janet Fyfe, Books Behind Bars: The Role of Books, Reading, and Libraries in British Prison Reform, 1701-1911 (Westport, 1992), p. 9.

${ }^{95}$ Jenny Hartley, 'Reading in Gaol', in Beth Palmer et al (eds) Return to the Common Reader: Print Culture and the Novel 1850-1900 (Farnham, 2011), p. 91.

${ }^{96}$ Argus, 31 March 1854, p. 4.

${ }^{97}$ Jean Ely, Reality and Rhetoric: An Alternative History of Australian Education (Sydney, 1978), p.

23.

${ }^{98}$ Ovens and Murray Advertiser, 10 July 1862, 2.

${ }^{99}$ Susan West, Bushranging and the Policing of Rural Banditry in New South Wales, 1860-1880 (North Melbourne, 2009), pp. 86-87.

${ }^{100}$ Alan Barcan, A History of Australian Education (Melbourne, 1980), p. 131.

${ }^{101}$ Age, 9 July 1918, p. 6.

${ }^{102}$ J.J. Tobias, Urban Crime in Victorian England (New York, 1972), pp. 172-176.

${ }^{103}$ Hamish Maxwell-Stewart, 'The Search for the Convict Voice', Tasmanian Historical Studies 6, no. 1 (1998), pp. 75-89.

${ }^{104}$ Mary Hogan, Register 10, 5521, VPRS 516/P1, PROV.

105 'Report with Minutes of Evidence taken before the Board of Inquiry appointed to enquire into the general management of the gaols, penal establishments, and lockups of the Colony of Queensland', Queensland Votes \& Proceedings vol. 1 (Brisbane, 1887), p. lxii.

${ }^{106}$ Castieau, Diaries, 21 May 1871.

${ }^{107}$ West, Bushranging, p. 87.

${ }^{108}$ Castieau, Diaries, 28 August 1874.

${ }^{109}$ William Henry Manwaring, Notes from His Diaries, Papers 1865-1897, MS 13674, State Library Victoria, p. 156. 
${ }^{110}$ Jones, ‘Public Libraries’, p. 166.

111 ‘Annual Report on Prisons, 1919’, Queensland Parliamentary Papers vol. 2 (Brisbane, 1920), p. 240.

112 'Penal Establishments and Gaols: Report of the Inspector-General for the year 1901', VPP vol. 2 (Melbourne, 1902), p. 4.

${ }^{113}$ Hume Nisbet, 'Little Bourke Street', in Edward Ellis Morris (ed), Cassel's Picturesque Australia (Sydney, 1888), p. 80.

${ }^{114}$ Rosalind Crone, 'The Great "Reading” Experiment: An Examination of the Role of Education in the Nineteenth-Century Gaol', Crime, History \& Societies 16, no. 1 (2012), p. 50.

${ }^{115}$ Ibid., pp. 56-58.

${ }^{116}$ Fyfe, Books Behind Bars, p. 177.

${ }^{117}$ Castieau, Diaries, 23 April 1871.

${ }^{118}$ Fitzroy City Press, 1 May 1903, p. 3.

${ }^{119}$ Rosalind Crone, 'Attempts to (Re)Shape Common Reading Habits: Bible Reading on the Nineteenth-Century Convict Ship', in Beth Palmer et al (eds), Return to the Common Reader: Print Culture and the Novel 1850-1900 (Farnham, 2011), p. 104.

${ }^{120}$ Helen Rogers, 'The Way to Jerusalem: Reading, Writing and Reform in an Early Victorian Gaol', Past and Present 205, no. 1: p. 72.

${ }^{121}$ George Edwards, Papers 1870-1930, MS 11990, SLV.

${ }^{122}$ Fyfe, Books Behind Bars, p. 176.

123 'Penal Establishments and Gaols Report of the Inspector-General for the year 1890', VPP vol. 3 (Melbourne, 1891), p. 11.

${ }^{124}$ Janet Dibben, Songs and Recitations; Written and Composed from Experience by a Lady That Has Travelled (St Kilda, 1904), pp. 8-9.

${ }^{125}$ Alana Piper, “'I Go Out Worse Every Time”: Connections and Corruption in a Female Prison', History Australia 9, no. 3 (2012), p. 138.

${ }^{126}$ Regina v Amy Cramer, 548a/1892, VPRS 30/P0, PROV.

${ }^{127}$ Rex v Elizabeth Wilson and Margaret Dougan, 555/1915, VPRS 30/P0, PROV.

${ }^{128}$ Melissa Bellanta and Alana Piper, 'Looking Flash: Disreputable Women's Dress and "Modernity", 1870-1910', History Workshop Journal 78, no. 1 (2014), p. 68. 
${ }^{129}$ Argus, 29 June 1876, p. 4. 